UNIVERSITY OF MISSOURI COLLEGE OF AGRICULTURE AGRICULTURAL EXPERIMENT STATION

J. H. LONGWELL, Director

\title{
Solar Energy
}

A SUMMARY OF RECORDS AT COLUMBIA, MISSOURI

James D. McQuigg and Wayne L. Decker

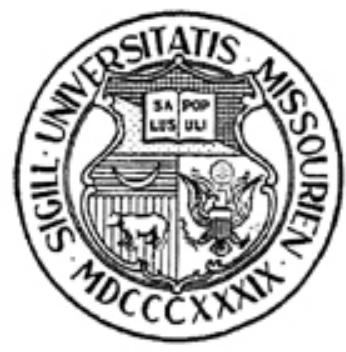

(Publication authorized July 24, 1958)

COLUMBIA, MISSOURI 


\section{SUMMARY}

The sun is a constant and dependable source of energy. But each year there are seasonal trends in the amount of energy reaching the surface of the earth. These trends are due to regular changes in the tilt of the earth on its axis.

The greater the angle at which the rays of the sun strike the earth's surface, the more intense is the sun's energy. For this reason, when the sun is high overhead, more energy is received on a given area than when the sun is low on the horizon. To demonstrate this, one need only to visualize the daily trend in solar radiation. At sunrise the sun is low in the sky and the intensity of energy is not great. As the day progresses the sun becomes higher and the intensity of energy increases, reaching a maximum at noon. During the afternoon the events are reversed and the intensity of energy from the sun decreases until sunset. These daily trends in energy are shown in Figures 6, 7,8 and 9.

Through the year, there are seasonal changes in the height of the sun. In winter the sun is low on the horizon and there is a low intensity of solar energy. In summer the sun is high and larger radiation intensities result. In the northern hemisphere, the sun is lowest in the sky on December 21 and gradually increases its height as the winter season proceeds and as spring passes. At all points north of the equator, the sun reaches its highest point above the horizon on June 22; it then recedes until December 21 finds the sun again at its lowest point.

Associated with the seasonal changes of the height of the sun above the horizon are variations in the length of daylight. On days when the duration of light is short there is less opportunity for solar radiation to reach the surface of the earth than during periods when duration of daylight is long. In the northern hemisphere December 21 has the shortest duration of daylight. The length of daylight increases through the winter and spring until June 22 when the duration of daylight is at its maximum. The length of the daylight period becomes shorter as summer and fall pass.

The seasonal rhythm of the length of daylight and the height of the sun produces a cycle in the amount of energy received at the surface of the earth. The smallest amounts of solar radiation occur in late December with the greatest amount being received in late June. This seasonal rhythm is revealed in Figures $3,12,13$, and 14. In Missouri, each square centimeter of horizontal surface receives more than 600 calories of heat from the sun on an average day in late June and 150 calories in late December.

The seasonal rhythm in solar radiation is often interrupted when the solar radiation is intercepted by liquid drops of water in clouds and fog or by the solid particles in dust and smoke. When this occurs, solar radiation reaches the earth in variable amounts. These variations are indicated in the data of Figure 4 and Tables 2, 3, 4, and 5 .

To estimate the solar radiation received during periods when the seasonal rhythm was interrupted by clouds, fog, dust or smoke, solar radiation was re- 
lated to the "percent of possible sunshine." The regression equations from this analysis are in the Appendix. On the average the "percent possible sunshine" provides an estimate of solar radiation within 2 percent of the measured average values. For estimating radiation on individual days the error may be considerably greater.

\section{TABLE OF CONTENTS}

Solar Radiation - a Source of Heat $\ldots \ldots \ldots \ldots \ldots \ldots \ldots \ldots \ldots \ldots$

Records of Solar Radiation $\ldots \ldots \ldots \ldots \ldots \ldots \ldots \ldots \ldots$

Seasonal Distribution of Solar Radiation $\ldots \ldots \ldots \ldots \ldots \ldots \ldots .8$

Daily Totals of Solar Radiation $\ldots \ldots \ldots \ldots \ldots \ldots \ldots \ldots$

Hourly Totals of Solar Radiation .................. 9

Daily Values of Solar Radiation and "Percent of Possible"

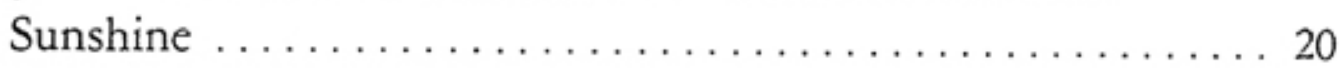

Comparative Estimates of Solar Radiation for Other

Geographic Locations ....................... 22

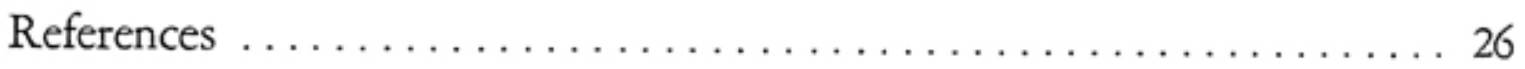

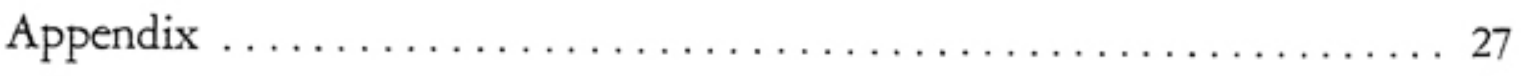

This bulletin reports on Department of Soils

Research Project 281, Climate. 


\section{Solar Energy}

\section{SOLAR RADIATION-A SOURCE OF HEAT}

Solar energy comes from the sun in a steady flow, with comparatively minor fluctuations. It has been reported by Fritz (1) that the total energy received from the sun at the top of the atmosphere varies in time by only a factor of 1 or 2 percent. After passing through the atmosphere to a point on the surface of the earth, solar radiation arrives as a highly variable quantity. This study was undertaken to portray the daily and seasonal patterns in solar radiation as received at the earth's surface under Missouri's climatic conditions.

Radiation from the sun is the basic source of all non-nuclear energy on earth. The exchange of this heat at the surface of the earth is shown in Figure 1. A portion of this energy heats the soil; some is spent in evaporation from bodies of water and plant covers; some is transferred to the air; while the remainder leaves the earth's surface as radiant energy. There is also a smill portion of energy (less than 1 percent of full summer sunlight) absorbed in the complicated chemistry of plant growth. The quantity of energy used for each purpose is not constant but varies with the condition of the atmosphere and earth's surface.

Although the sun has long been recognized as a source of energy, man has only begun to make direct use of this energy. Buildings are now being designed which utilize solar energy during the heating season. On the farrn, power from the sun is also being used for grain and hay drying in a system designed by Buelow (2).

Biological responses are dependent upon the intensities of solar energy. Penman (3) and other investigators have demonstrated that the intensity of solar energy determines the amount of water transpired from plants or evaporated from free water surfaces. Accordingly, the frequency and amount of irrigation applications will be dependent upon the intensity of solar radiation. Fruit-setting in apples and other trees is determined by the intensity of solar energy received during the post bloom stage according to Gardner, et al. (4).

The botanist and the engineer have a demonstrated need for information about the intensities of solar energy. To fulfill this need, they must have available records of the measurements of solar radiation. Such records have been taken at Columbia, Mo., and are summarized in this bulletin.

Records of Solar Radiation

Solar Radiation data used in this study were obtained from an Eppley Pyrheliometer. This instrument, shown in Figure 2, measures the radiation fall- 


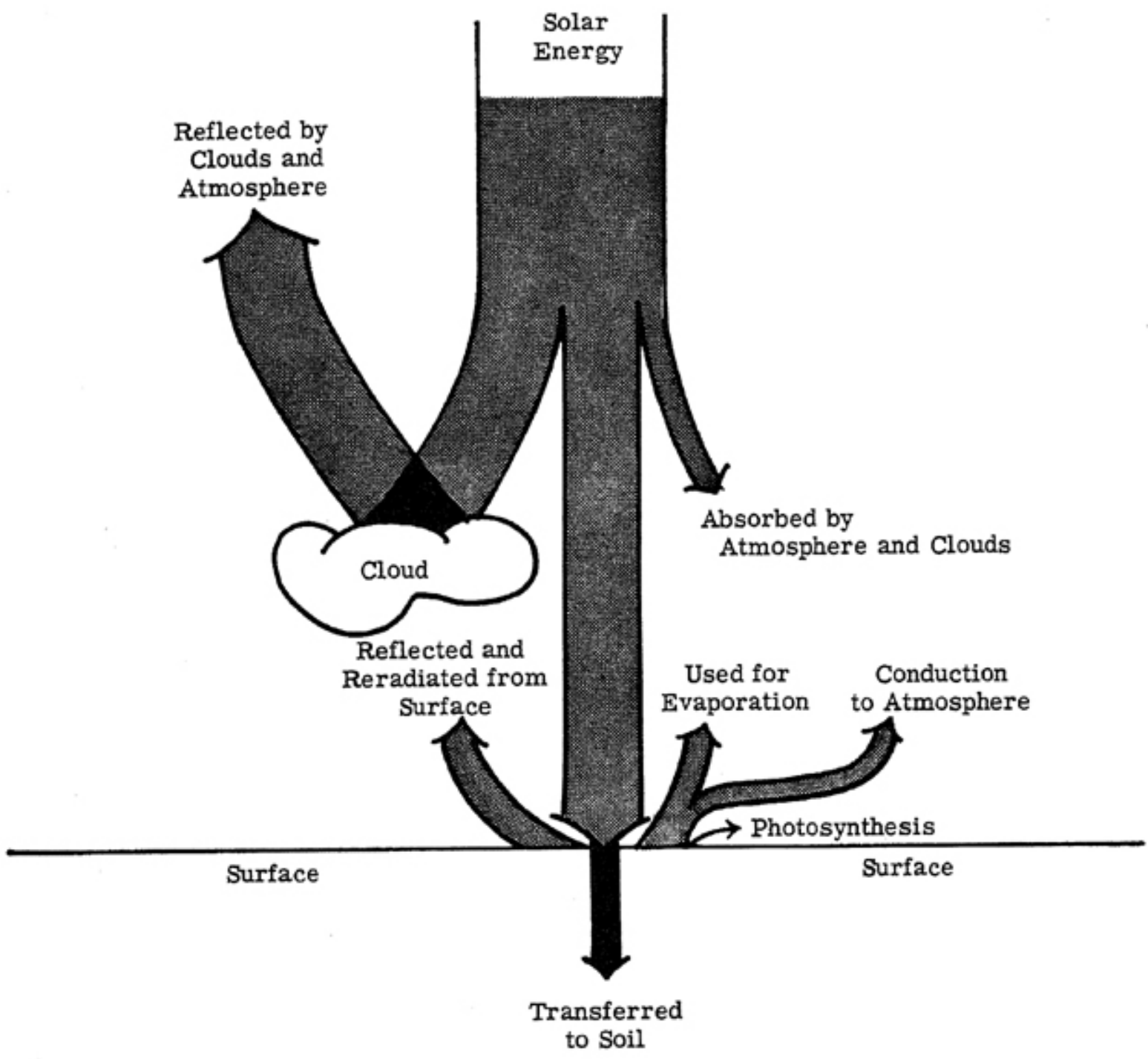

Fig. 1-A schematic diagram showing the distribution of solar energy at midday during the summer season.

ing on a horizontal surface at the bottom of the atmosphere. The basic unit of measurement of solar radiation is calories of energy per square centimeter* of horizontal surface for a specified length of time.

The Epply Pyrheliometer is a specialized thermopile made from wire of 0.0016 inch diameter. One wire of the thermopile is an alloy of 60 percent gold and 40 percent palladium while the second wire is an alloy of 90 percent platinum and 10 percent rhodium. Alternate junctions of the thermopile are in thermal contact with, but electrically insulated from, concentric silver rings of 0.01 inch thickness. The inner silver ring is painted with lamp black while the outer ring is made white by magnesium oxide smoke. According to the manufacturer (5) these blackened and whitened surfaces absorb long wave radiation with equal ease; but the nagnesium oxide reflects most of the short wave radia-

*Another unit of measurement which is often employed by engineers is $\mathrm{BTU} / \mathrm{ft}^{2}$ where $1 \mathrm{BTU} / \mathrm{ft}^{2}=.27 \mathrm{cal} / \mathrm{cm}^{2}$. 


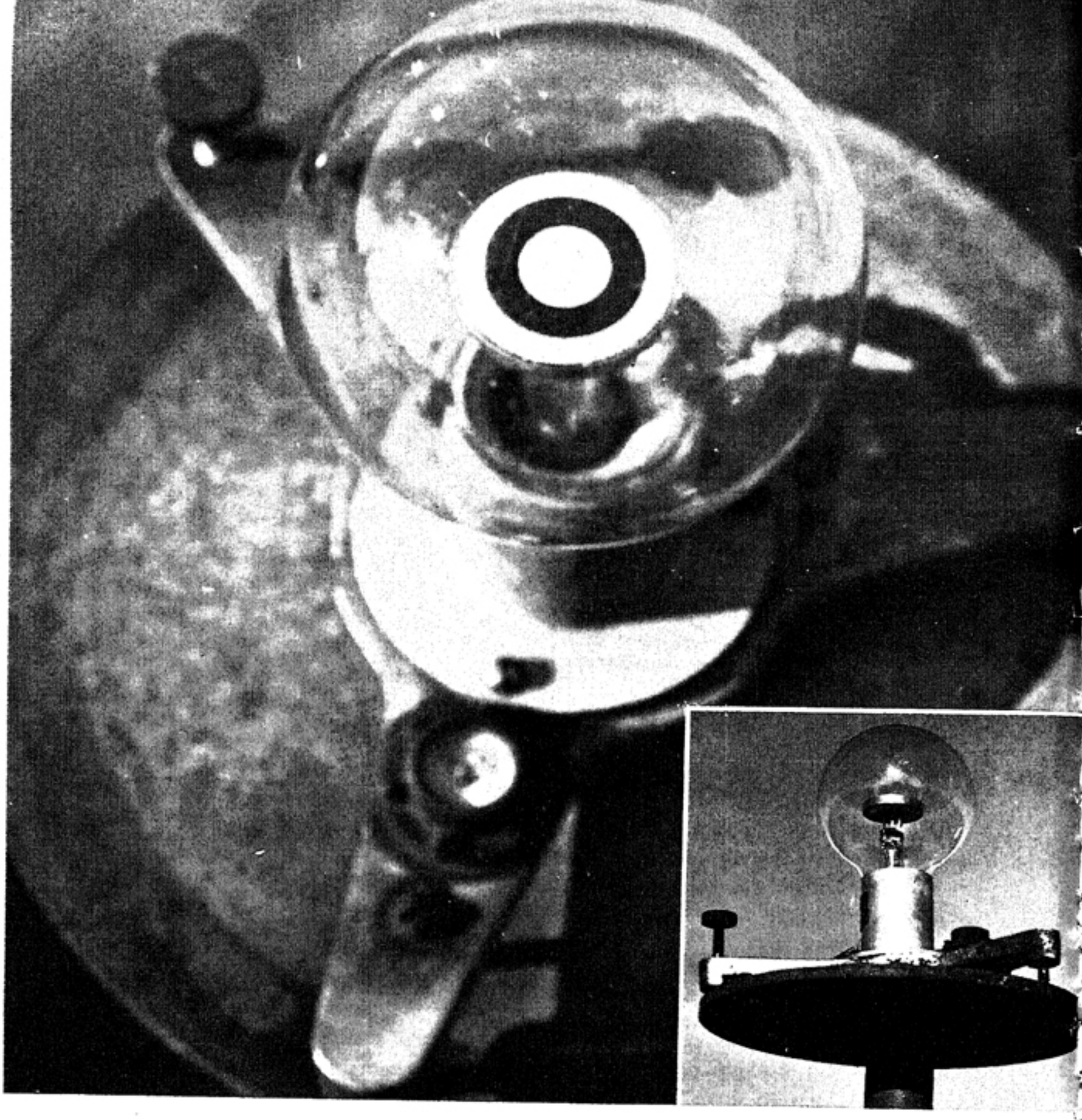

Fig. 2-The Epply Pyrheliometer which is used to measure solar energy. The inset pictures the instrument on a rooftop being exposed to the sun's rays. The large picture is a close-up of the sensing element, viewed from above. 
tion received from the sun. When exposed to radiation of short wave lengths the two silver rings of the pyrheliometer develop a temperature difference. The resulting electromotive force in the thermopile is approxirnately proportional to intensity of radiation. The intensity of energy is recorded by a precision potentiometer.

The receiving element of the pyrheliometer, which comprises the silver rings and thermopile, is hermetically sealed in a lamp bulb. This bulb, which is rnade of soda lime glass, is filled with dry air when the unit is assembled. The bulb is 3 inches in diameter and, when mounted on its $71 / 2$-inch diameter base, stands to a height of $6 \frac{1}{2}$ inches.

Records of solar radiation have been made at Columbia, Mo., $\left(38^{\circ} 58^{\prime} \mathrm{N}\right.$. $92^{\circ} 22^{\prime} \mathrm{W}$. Longitude) for the past 14 years. From February, 1944, to October 20, 1949 , the pyrheliometer was located above the horticulture greenhouse on the campus of the University of Missouri. It was moved to the roof of the Post Office building late in 1949 and the recording of data was resumed on December 14. On July 13, 1951, the equipment was moved to its present location on the roof of the Weather Bureau Airport Station.

Hourly and daily totals of solar radiation for the period of record have been placed on IBM punched cards through a cooperative agreement between the University of Missouri and the U. S. Weather Bureau. The description of the method for processing these data has been presented elsewhere (6). 


\section{SEASONAL DISTRIBUTION OF SOLAR RADIATION}

\section{Daily Totals of Solar Radiation}

Much of the seasonal variation in solar radiation at Columbia is the result of changes in the height of the sun above the horizon. During winter, when the sun is low on the horizon, a small amount of energy is received on a given horizontal area, but in summer when the sun is high a larger amount arrives on the sarne area.

The length of the daylight period is another factor which causes a seasonal change in radiation, since longer lengths of daylight result in greater amounts of energy. The length of day at Columbia varies from 15 hours in late June to $91 / 2$ hours in late December. Day length and the height of the sun above the horizon change together so that the sun's intensity and duration are both greater in summer than winter.

The average intensity of solar radiation received on each day is shown in Figure 3. It will be noted that the expected seasonal variation occurs along with many rninor fluctuations.

Another element which contributes to the seasonal differences in daily radiation is the change in cloudiness from month to month. The mean numbers of clear, partly cloudy, and cloudy days (sunrise to sunset) at Columbia for the past 67 years of record are shown in Table 1.

Fig. 3-Averages of solar radiation received for each day of the year. Each point represents the average for a five-day period during the years 1944 through 1956.

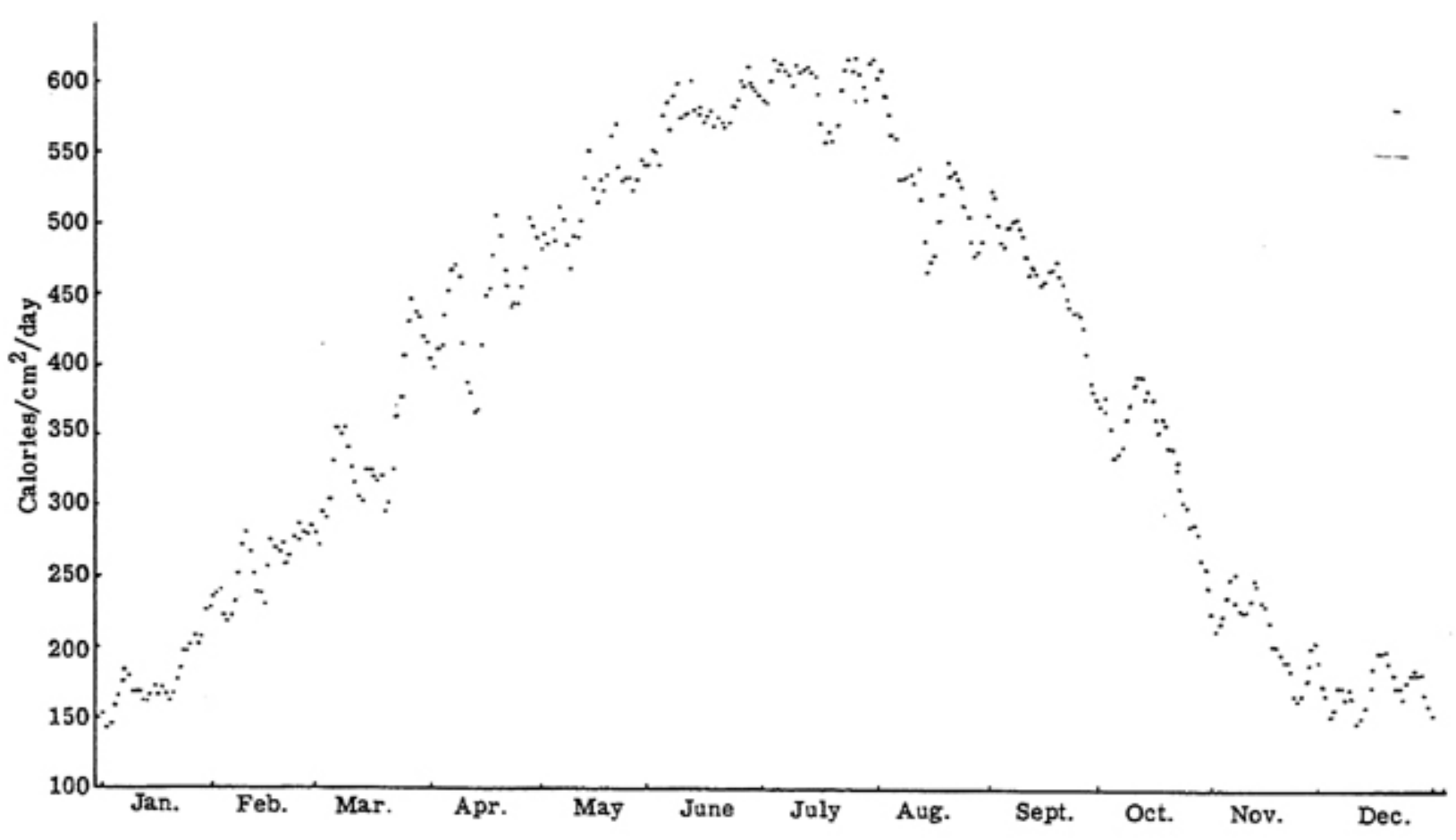


TABLE 1. SEASONAL DISTRIBUTION OF CLOUDINESS AT COLUMBIA, MO.

\begin{tabular}{|c|c|c|c|c|c|c|c|c|c|c|c|c|}
\hline \multirow{2}{*}{$\begin{array}{l}\text { Cloudi- } \\
\text { ness }\end{array}$} & \multicolumn{12}{|c|}{ Mean Number of Days } \\
\hline & $\overline{\text { Jan. }}$ & Feb. & Mar. & Apr. & May & June & July & Aug. & Sept. & Oct. & Nov. & Dec. \\
\hline Clear & 10 & 9 & 9 & 9 & 9 & 10 & 14 & 14 & 14 & 15 & 12 & 9 \\
\hline Part & & & & & & & & & & & & \\
\hline Cloudy & 7 & 7 & 9 & 9 & 11 & 12 & 11 & 11 & 8 & 7 & 7 & 8 \\
\hline Cloudy & 14 & 12 & 13 & 12 & 11 & 8 & 6 & 6 & 8 & 9 & 11 & 14 \\
\hline
\end{tabular}

Fron early winter until early summer, there are many cloudy days. This is reflected in the frequency distributions of daily totals of solar energy shown in Figure 4 by the large percentage of days with low radiation during this portion of the year.

The months of June through October have a relatively small number of cloudy days. The frequency distributions of Figure 4 which are associated with these months display a large proportion of days with high radiation.

\section{Hourly Totals of Solar Radiation}

Radiation totals for each hour of the day reveal the day's pattern of solar energy. Since the daily distribution of energy is related to the time of the year and the amount of cloudiness, the hourly totals of solar energy have been classified according to the amount of cloud cover and the time of the year. Each hour with a solar radiation total has been classified according to the amount of cloud cover as clear, scattered, broken or overcast on the basis of weather observation during the hour. These observations of cloud cover were recorded at 25 minutes past the hour, Central Standard Time, and were assumed to be representative of cloud conditions through the solar hour.** There were undoubtedly times when these hourly observations were not representative, but in most cases the amount of cloud cover persists throughout the entire hour.

To demonstrate the effect of the time of year, each month was divided into three intervals and the hourly totals of solar radiation for each interval were assembled. The intervals were the period from the first through the tenth, the eleventh through the twentieth, and the twentieth to the end of the month. The trend of solar radiation through the day was shown by the average of hourly radiation totals for each period of the year. The daily trends corresponding to periods of the eleventh through the twentieth of March, June, September and Decem-

**Beginning with September 1, 1949, hourly values of solar radiation were tabulated on the basis of "mean solar time". Prior to this date the hourly values had been tabulated on a Central Standard Time basis so the earlier data are not comparable with those obtained during the past seven years. Solar time is a time scale for which noon occurs when the sun has attained its maximum height above the horizon. The corrections which should be added algebraically to Central Standard Time to arrive at "mean solar time" for any date at Columbia, Missouri are shown in Figure 5. 


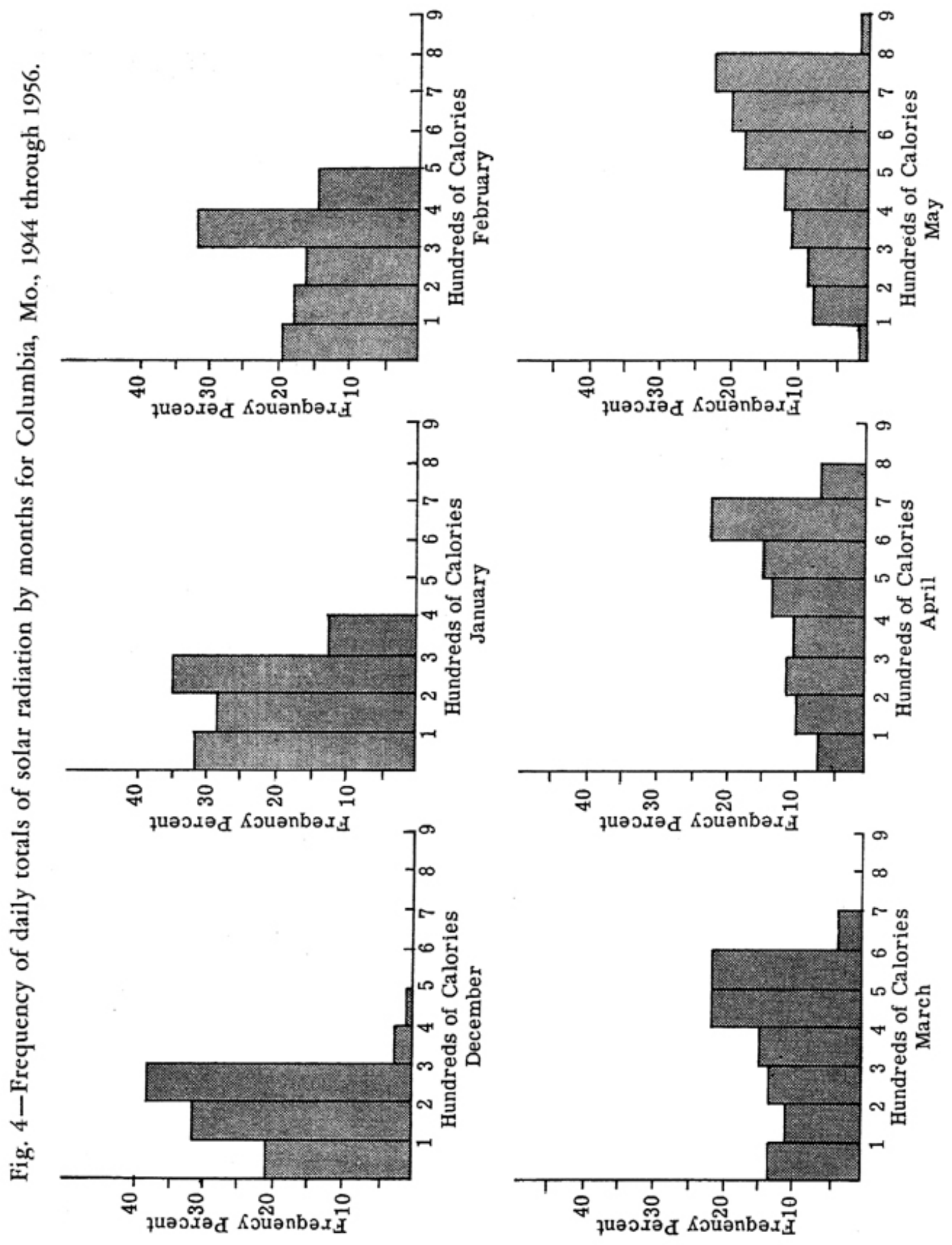



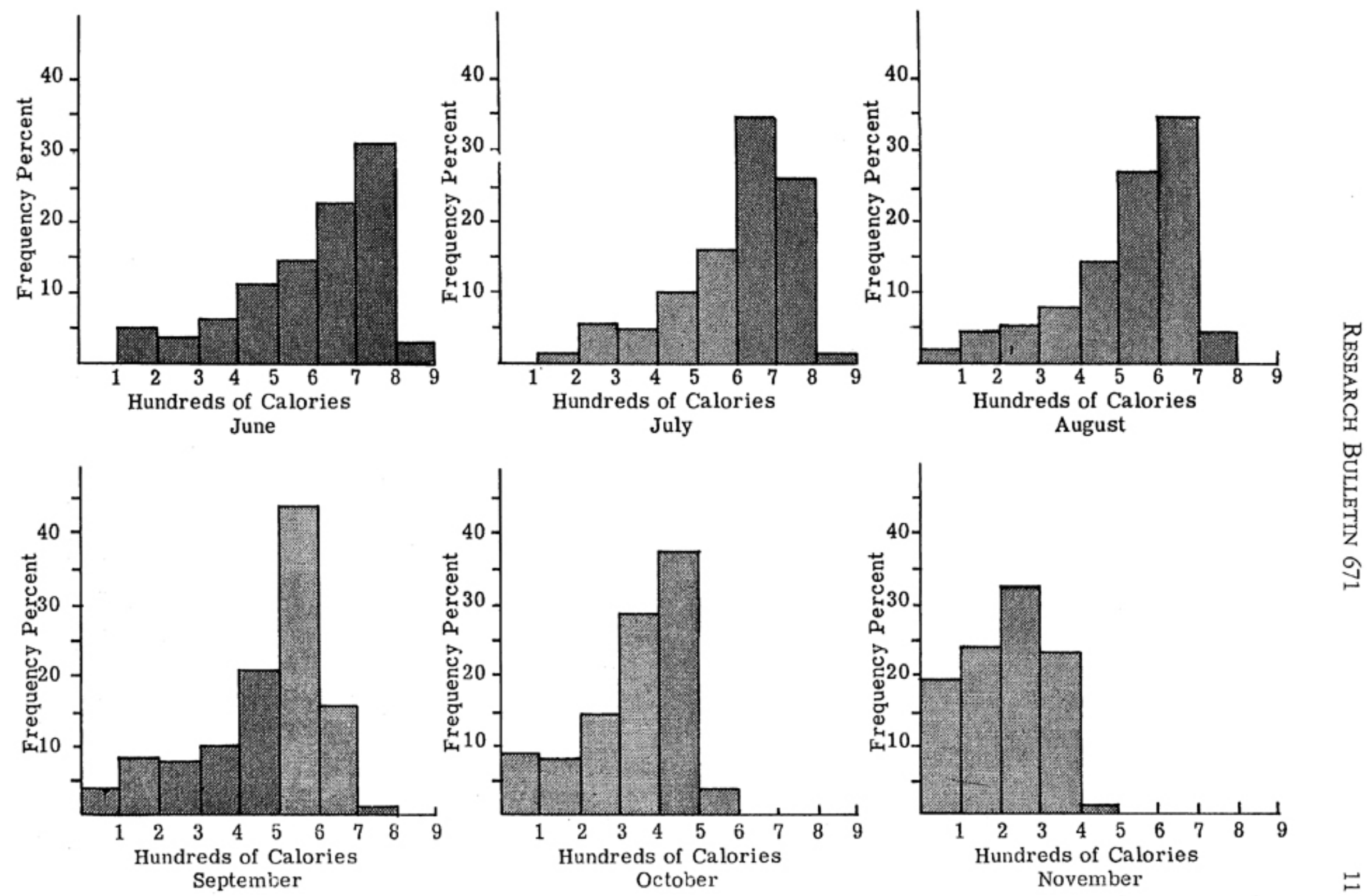


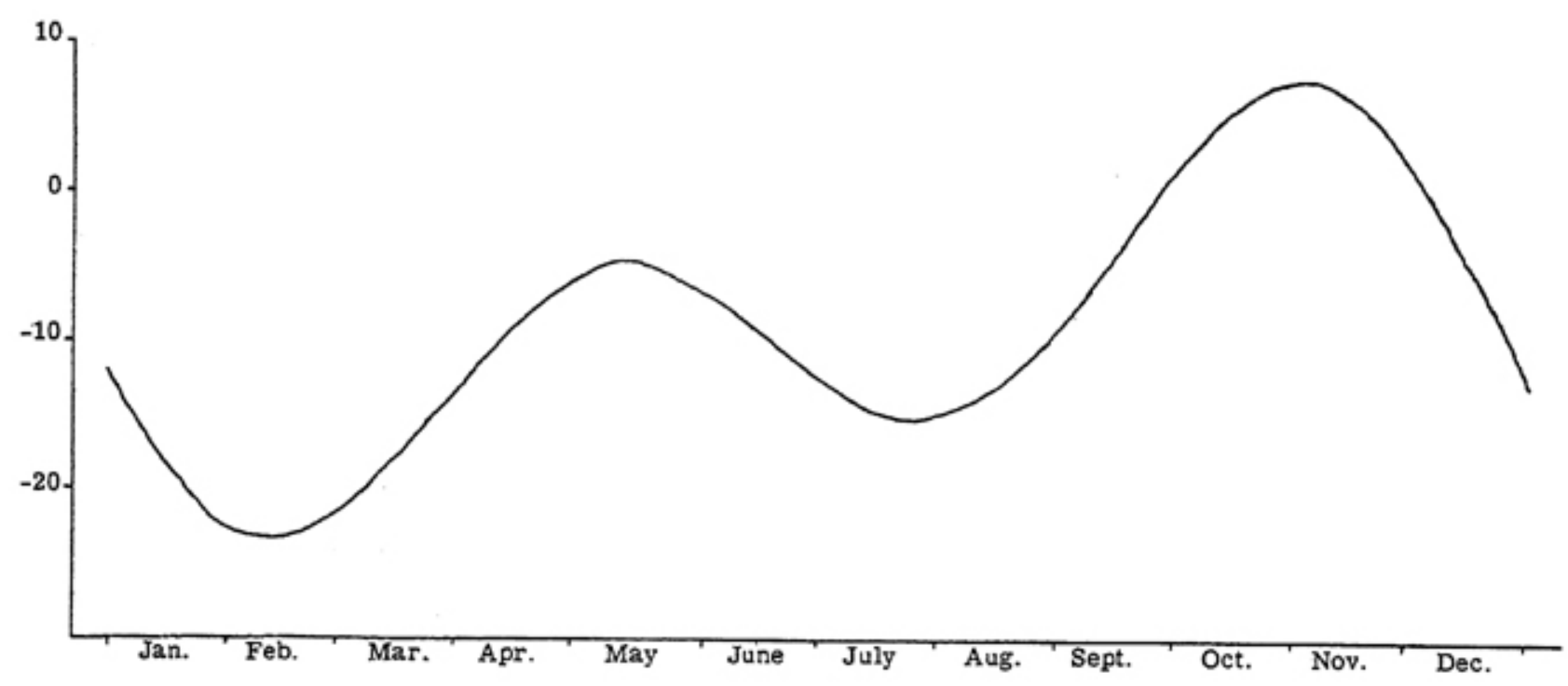

Fig. 5-Corrections for the conversions of central standard time to the mean solar time for Columbia, Mo.

ber are shown in Figures 6, 7,8, and 9. These four periods are given as examples because they represent the four seasons of the year. The vernal equinox (first day of spring) occurs on March 21; the summer solstice (first day of summer), on June 21; the autumnal equinox (first day of autumn), on September 22; and the winter solstice (first day of winter), on December 21.

The spread of the daily curve for each season, shown in Figures 6 through 9 , is indicative of the length of daylight. Energy is received from the sun as early as 4:30 a.m. and as late as 7:30 p.m. in mid-June, while none is received before 7:30 a.m. or after 4:45 p.m. during mid-December.

Note that scattered clouds (10 to 50 percent cloud cover) do not reduce the amount of energy received very much; even a sky condition with broken clouds ( 50 to 90 percent cloud cover) does not cause a great reduction in the amount of incoming energy. At mid-day, scattered clouds reduce the amount of energy received by about 5 percent while broken clouds cause a reduction of nearly 20 percent from the energy received with a clear sky. Scattered and broken clouds reduce the amount of energy received by only a small amount because much of the solar energy intercepted by the clouds is reflected to the earth's surface through the clear spaces between the clouds.

When skies are overcast (100 percent cloud cover), intercepted solar radiation has little opportunity of being reflected toward the surface. An average of about 60 percent less energy reaches the surface at noon on an overcast day than on a clear day, based on a yearly average. In summer, this percentage reduction of solar radiation by overcast skies is about 40 percent while in winter the reduction is 63 percent. 
Fig. 6-Average solar radiation for Mid-March by varying amounts of cloudiness.

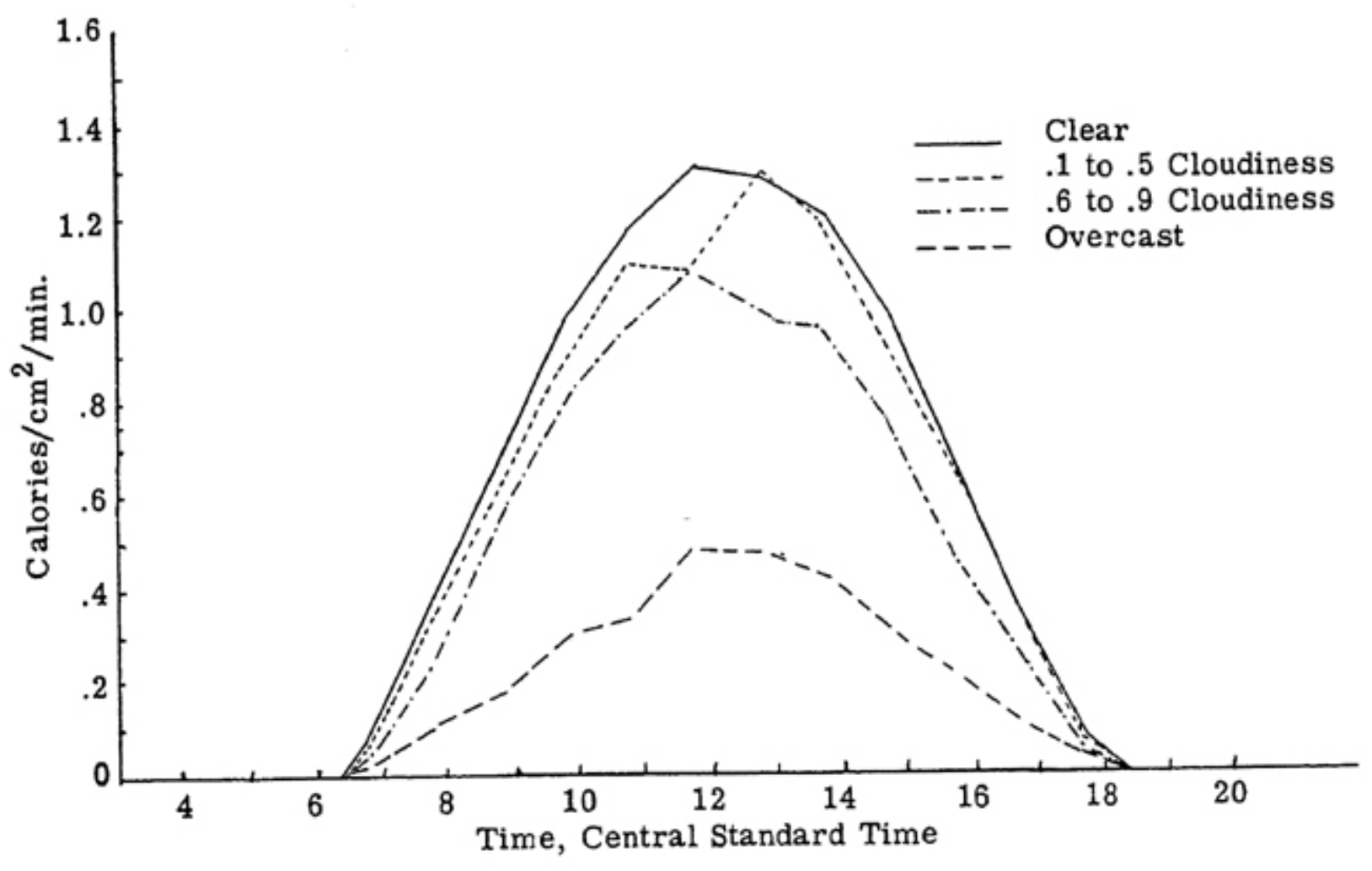

Fig. 7-Average solar radiation for Mid-June by varying amounts of cloudiness.

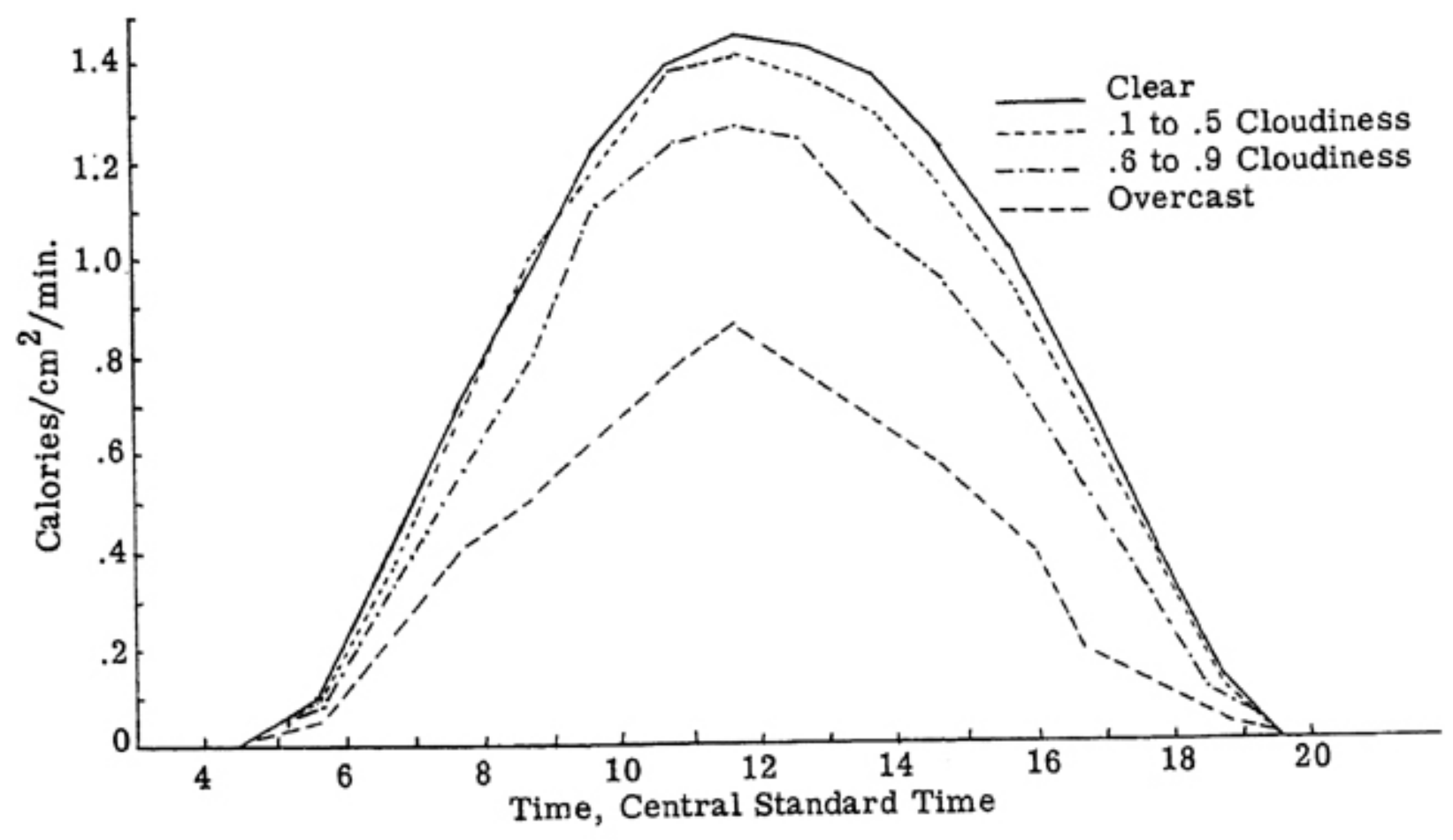


Fig. 8-Average solar radiation for Mid-September by varying amounts of cloudiness.

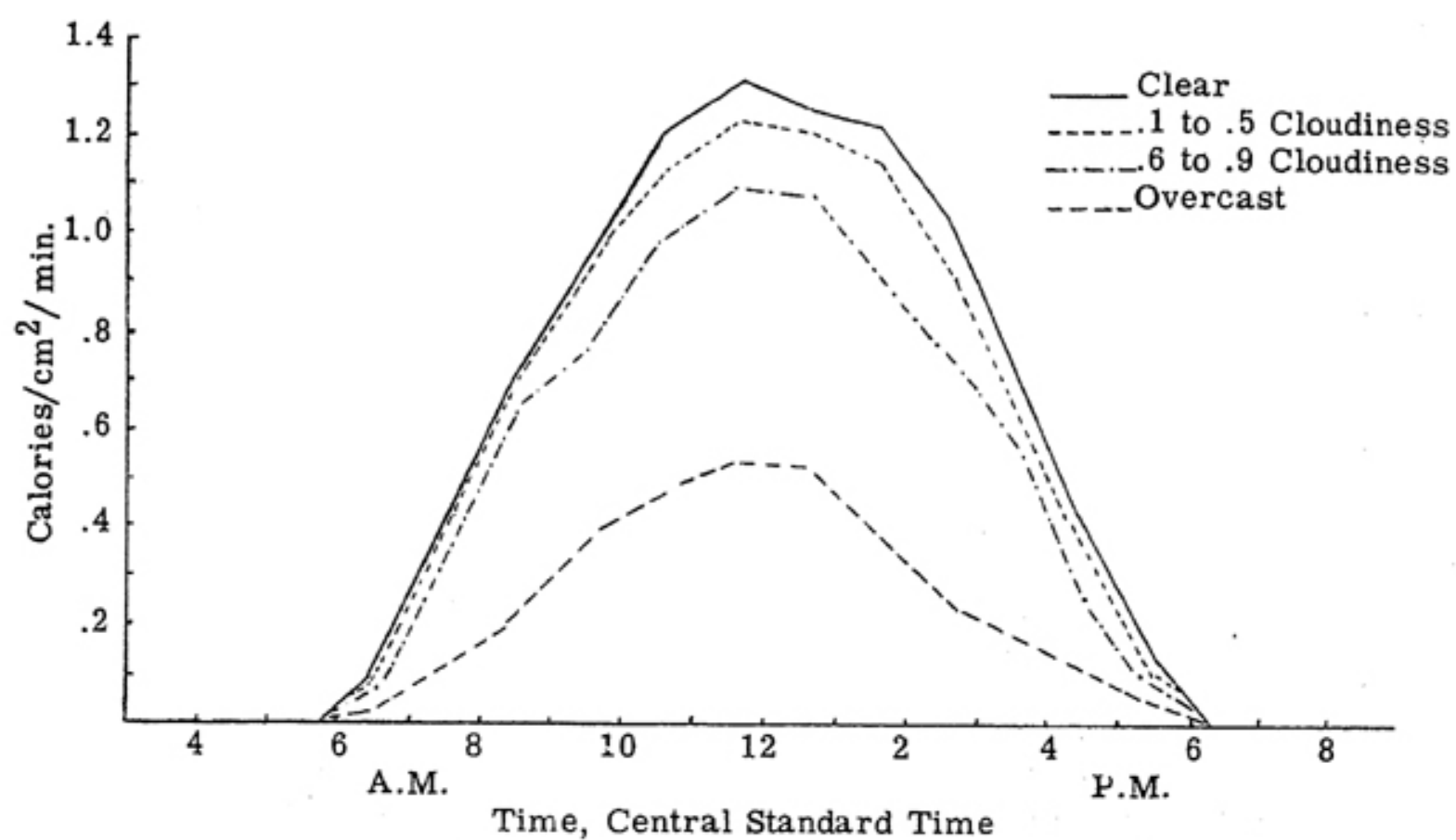

Fig. 9-Average solar radiation for Mid-December by varying amounts of cloudiness.

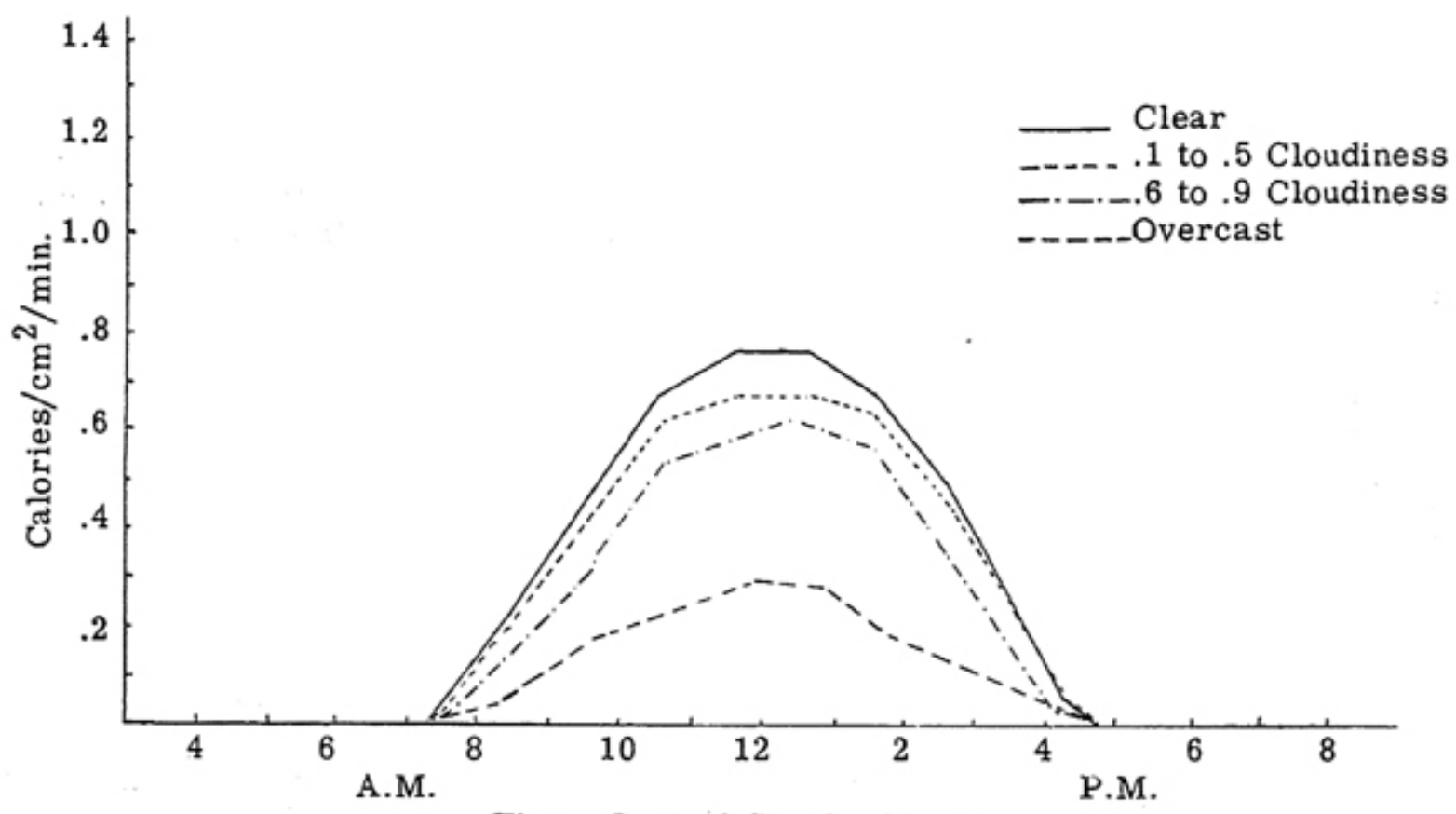

Time, Central Standard Time 
The dependability of the sun as a source of energy is important to the engineer when designing heating systems which utilize the sun as a source of heat. He must know how much variation to expect from the hourly averages reported in Figures 6 through 9. Frequency distributions which demonstrate the variation in hourly radiation totals are shown for varying cloud amounts in Tables 2, 3, 4, and 5. For each month the hourly totals of solar energy are clustered closely about the mean values when the skies are clear or contain scattered clouds. The total radiation has a greater tendency for dispersion from the mean value with broken clouds; with a complete cloud cover the hourly values are widely dispersed from the mean.

When there is less than 50 percent cloud cover, the radiation for any day may be estimated by the sum of the hourly averages which correspond to the period of the year in which the day occurs. The hourly averages of radiation become a poorer estimate of the actual radiation as the amount of cloudiness increases.

The large dispersion of hourly totals about the average for broken clouds and overcast conditions occurs because of the variation in density of the clouds and in thickness of the cloud layer. Since the height of the clouds above the ground was inversely related to the density and thickness of the clouds, it was thought that the hourly totals of radiation might be estirnated from the recorded height of the clouds. For this purpose linear regression equations, showing the relationship between cloud height and solar radiation, were computed for the hours with an overcast sky. The regression equations obtained for the hour beginning at 12:00 noon, solar time, are shown in Table 6 along with the resulting correlation coefficients. In these relationships " $\mathrm{s}$ " is the estimated solar radiation in calories per square centimeter per hour and " $h$ " is the height of the base of the clouds in hundreds of feet.

The relationships between solar radiation and cloud height were disappointing. During the warm season of the year, the cloud height failed to explain a significant amount of the variation in solar radiation. Even during periods with significant correlation coefficients, less than half of the variation in solar energy is explained by the height of clouds. The amount of the variation in solar energy explained by cloud height was 42 percent for mid-January, 40 percent for midMarch and 38 percent for mid-November.

Less than half of the dispersion in the hourly totals of solar energy for overcast skies as shown in Tables 2 through 5 can be removed by a regression analysis using cloud height as the independent variable. It is apparent that cloud height as observed at a given time during an hour is not closely related to the total energy reaching the surface over the entire hour. It should be recalled that the intensity of solar radiation is not directly affected by the height of clouds, but is determined by the thickness and composition of the layer of clouds.

These results indicate that estimates of hourly values of solar energy based on cloud heights are subject to considerable error during cloudy weather. At- 
TABLE 2. FREQUENCY OF HOURLY RADIA TION FOR MARCH 11-20 FOR THE PERIOD 1949-1956 AT COLUMBLA, MO. Class

Interval

Number of Occurrences

\begin{tabular}{|c|c|c|c|c|c|c|c|c|c|c|c|c|c|c|c|c|c|c|c|}
\hline \multirow{3}{*}{$\begin{array}{l}\text { Sky } \\
\text { Cover }\end{array}$} & \multirow{3}{*}{$\begin{array}{c}\text { Interval } \\
\text { of Solar } \\
\text { Radiation }\end{array}$} & \multicolumn{18}{|c|}{ Number of Occurrences } \\
\hline & & \multicolumn{18}{|c|}{ Hour } \\
\hline & & 04 & 05 & 06 & 07 & 08 & 09 & 10 & 11 & 12 & 13 & 14 & 15 & 16 & 17 & 18 & 19 & 20 & 21 \\
\hline \multirow[t]{8}{*}{ Clear } & $\begin{array}{l}00-09 \\
10-19\end{array}$ & & 3 & 16 & 3 & & & & & & & & & 4 & 11 & & & & \\
\hline & $20-29$ & & & & 11 & & & & & & & & 1 & $\begin{array}{l}4 \\
7\end{array}$ & & & & & \\
\hline & $30-39$ & & & & & 4 & & & & & & & 2 & & & & & & \\
\hline & $40-49$ & & & & & 10 & & & & & & & 6 & & & & & & \\
\hline & $50-59$ & & & & & & 5 & & & & & 4 & & & & & & & \\
\hline & $60-69$ & & & & & & 3 & 4 & & 1 & 3 & 5 & & & & & & & \\
\hline & $70-79$ & & & & & & & 4 & 7 & 8 & 7 & & & & & & & & \\
\hline & $\begin{array}{l}80-89 \\
90-99\end{array}$ & & & & & & & & 2 & 2 & & & & & & & & & \\
\hline
\end{tabular}

\begin{tabular}{|c|c|c|c|c|c|c|c|c|c|c|c|c|c|c|}
\hline Scattered & $\begin{array}{l}00-09 \\
10-19 \\
20-29 \\
30-39 \\
40-49 \\
50-59 \\
60-69 \\
70-79 \\
80-89 \\
90-99\end{array}$ & 2 & 8 & $\begin{array}{l}4 \\
4\end{array}$ & $\begin{array}{l}1 \\
5 \\
6\end{array}$ & $\begin{array}{r}1 \\
3 \\
10 \\
2\end{array}$ & $\begin{array}{r}2 \\
8 \\
2\end{array}$ & $\begin{array}{l}1 \\
1 \\
2 \\
5 \\
1\end{array}$ & $\begin{array}{l}1 \\
3 \\
3\end{array}$ & $\begin{array}{l}3 \\
3\end{array}$ & $\begin{array}{l}3 \\
6 \\
1\end{array}$ & $\begin{array}{l}4 \\
6\end{array}$ & $\begin{array}{l}3 \\
6\end{array}$ & 14 \\
\hline Broken & $\begin{array}{l}00-09 \\
10-19 \\
20-29 \\
30-39 \\
40-49 \\
50-59 \\
60-69 \\
70-79 \\
80-89 \\
90-99\end{array}$ & 2 & 11 & $\begin{array}{l}1 \\
6\end{array}$ & $\begin{array}{l}3 \\
5 \\
1\end{array}$ & $\begin{array}{l}4 \\
2 \\
4 \\
1\end{array}$ & $\begin{array}{l}2 \\
4 \\
1 \\
6 \\
4\end{array}$ & $\begin{array}{l}1 \\
3 \\
2 \\
1 \\
3 \\
4\end{array}$ & $\begin{array}{l}2 \\
1 \\
1 \\
2 \\
2 \\
2 \\
3\end{array}$ & $\begin{array}{l}2 \\
3 \\
2 \\
4 \\
3\end{array}$ & $\begin{array}{l}2 \\
2 \\
3 \\
4 \\
2\end{array}$ & $\begin{array}{l}2 \\
5 \\
5 \\
2\end{array}$ & $\begin{array}{l}1 \\
7 \\
3\end{array}$ & 7 \\
\hline Overcast & $\begin{array}{l}00-09 \\
10-19 \\
20-29 \\
30-39 \\
40-49 \\
50-59 \\
60-69 \\
70-79 \\
80-89 \\
90-99 \\
\end{array}$ & 5 & 31 & $\begin{array}{r}33 \\
8\end{array}$ & $\begin{array}{r}22 \\
7 \\
4 \\
2\end{array}$ & $\begin{array}{r}14 \\
9 \\
5 \\
5 \\
0 \\
1 \\
1\end{array}$ & $\begin{array}{r}10 \\
11 \\
4 \\
4 \\
2 \\
1 \\
1\end{array}$ & $\begin{array}{l}8 \\
8 \\
6 \\
4 \\
4 \\
2 \\
4 \\
1\end{array}$ & $\begin{array}{l}9 \\
7 \\
8 \\
6 \\
3 \\
2 \\
2 \\
2\end{array}$ & $\begin{array}{r}7 \\
12 \\
6 \\
7 \\
2 \\
4 \\
2\end{array}$ & $\begin{array}{r}13 \\
11 \\
7 \\
3 \\
3 \\
1\end{array}$ & $\begin{array}{r}18 \\
12 \\
3 \\
2 \\
2\end{array}$ & $\begin{array}{r}31 \\
8\end{array}$ & 38 \\
\hline
\end{tabular}


TABLE 3. FREQUENCY OF HOURLY RADIATION FOR JUNE 11-20 FOR THE PERIOD $1949-1956$ AT COLUMBIA, MO.

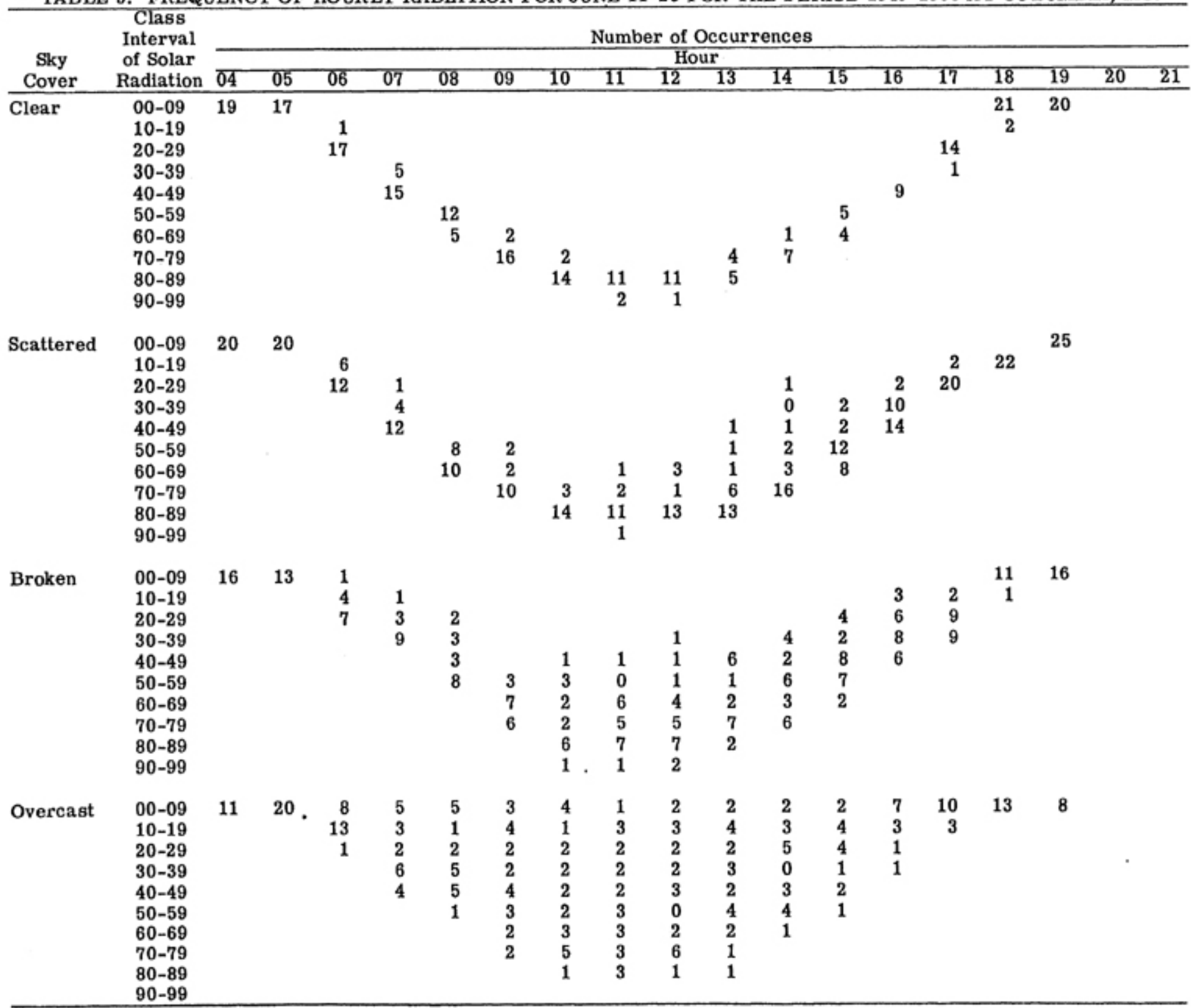


TABLE 4. FREQUENCY OF HOURLY RADIATION FOR SEPTEMBER 11-20 FOR THE PERIOD 1949-1956 A T COLUMBIA, MO.

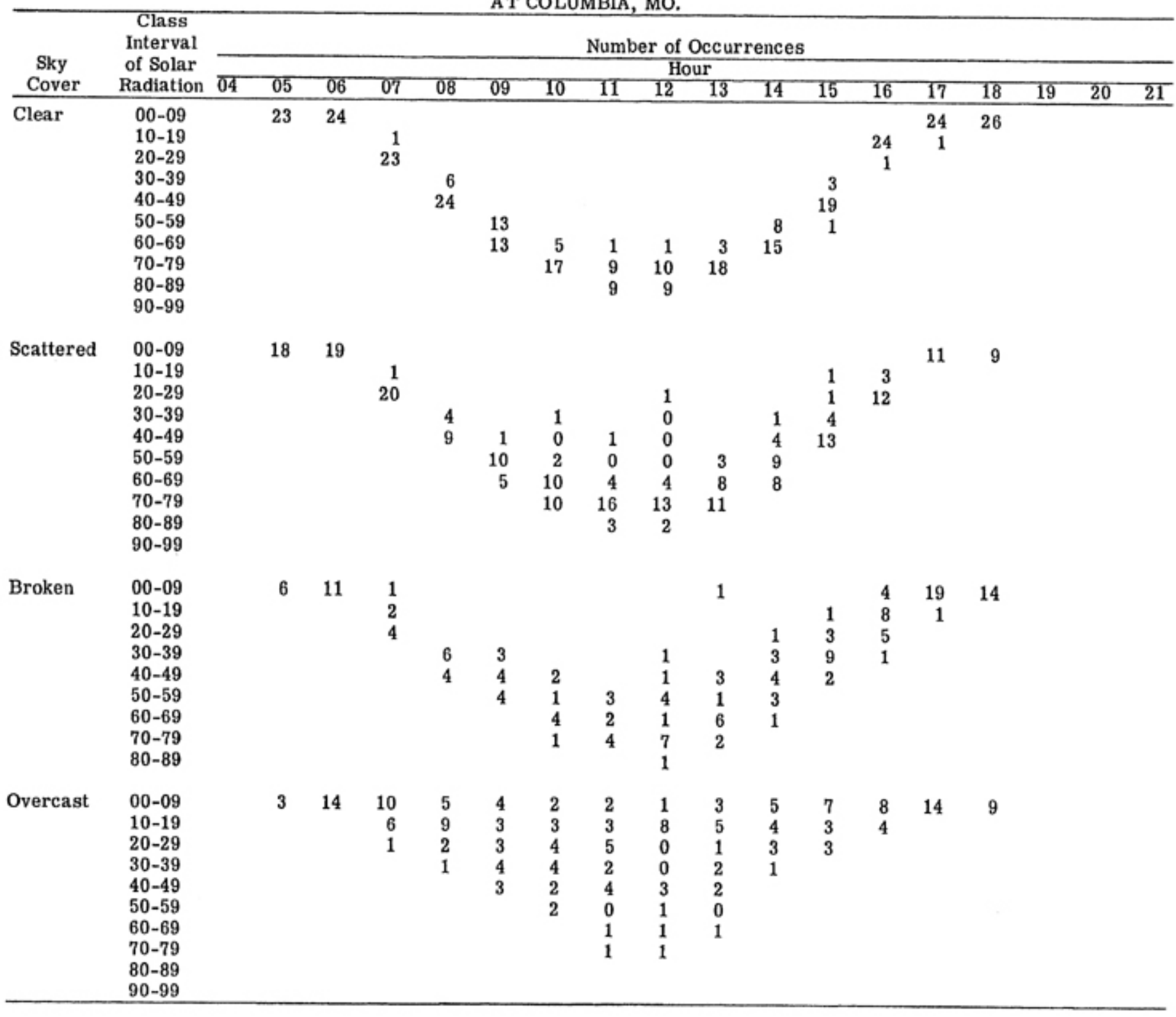


TABLE 5. FREQUENCY OF HOURLY RADIA TION FOR DECEMBER 11-20 FOR THE PERIOD 1949-1956 AT COLUMBIA, MO.

\begin{tabular}{|c|c|c|c|c|c|c|c|c|c|c|c|c|c|c|c|c|c|c|c|}
\hline \multirow{2}{*}{$\begin{array}{c}\text { Sky } \\
\text { Cover }\end{array}$} & \multirow{2}{*}{$\begin{array}{c}\text { Class } \\
\text { Interval } \\
\text { of Solar } \\
\text { Radiation }\end{array}$} & \multicolumn{18}{|c|}{ Number of Occurrences } \\
\hline & & 04 & 05 & 06 & 07 & 08 & 09 & 10 & 11 & 12 & 13 & 14 & 15 & 16 & 17 & 18 & 19 & 20 & 21 \\
\hline Clear & $\begin{array}{l}00-09 \\
10-19 \\
20-29 \\
30-39 \\
40-49 \\
50-59 \\
60-69 \\
70-79 \\
80-89\end{array}$ & & & & 13 & $\begin{array}{r}1 \\
10\end{array}$ & $\begin{array}{l}6 \\
7\end{array}$ & $\begin{array}{l}5 \\
7\end{array}$ & $\begin{array}{r}13 \\
4\end{array}$ & $\begin{array}{r}14 \\
4\end{array}$ & $\begin{array}{r}11 \\
7\end{array}$ & $\begin{array}{r}10 \\
7\end{array}$ & 17 & 18 & & & & & \\
\hline Scattered & $\begin{array}{l}00-09 \\
10-19 \\
20-29 \\
30-39 \\
40-49 \\
50-59 \\
60-69 \\
70-79 \\
80-89\end{array}$ & & & & 8 & $\begin{array}{l}2 \\
7\end{array}$ & $\begin{array}{l}1 \\
5 \\
2\end{array}$ & $\begin{array}{l}6 \\
1\end{array}$ & $\begin{array}{l}1 \\
5\end{array}$ & $\begin{array}{l}1 \\
1\end{array}$ & $\begin{array}{l}3 \\
2\end{array}$ & $\begin{array}{l}6 \\
1\end{array}$ & $\begin{array}{l}1 \\
7\end{array}$ & $\begin{array}{r}10 \\
1\end{array}$ & & & & & \\
\hline Broken & $\begin{array}{l}00-09 \\
10-19 \\
20-29 \\
30-39 \\
40-49 \\
50-59 \\
60-69 \\
70-79 \\
80-89\end{array}$ & & & & 9 & $\begin{array}{r}10 \\
5\end{array}$ & $\begin{array}{l}1 \\
3 \\
9\end{array}$ & $\begin{array}{l}2 \\
4 \\
7 \\
1\end{array}$ & $\begin{array}{l}1 \\
4 \\
3\end{array}$ & $\begin{array}{l}1 \\
5 \\
4\end{array}$ & $\begin{array}{l}4 \\
9 \\
2\end{array}$ & $\begin{array}{l}7 \\
7\end{array}$ & $\begin{array}{l}7 \\
6\end{array}$ & 14 & & & & & \\
\hline Overcast & $\begin{array}{l}00-09 \\
10-19 \\
20-29 \\
30-39 \\
40-49 \\
50-59 \\
60-69 \\
70-79 \\
80-89 \\
90-99 \\
\end{array}$ & & & & 34 & $\begin{array}{r}31 \\
1\end{array}$ & $\begin{array}{r}17 \\
13 \\
3\end{array}$ & $\begin{array}{r}10 \\
19 \\
3 \\
2\end{array}$ & $\begin{array}{r}10 \\
15 \\
9 \\
2\end{array}$ & $\begin{array}{r}11 \\
15 \\
7 \\
3 \\
1\end{array}$ & $\begin{array}{r}11 \\
16 \\
1 \\
1\end{array}$ & $\begin{array}{r}22 \\
7\end{array}$ & $\begin{array}{r}27 \\
2\end{array}$ & 24 & & & & & \\
\hline
\end{tabular}


TABLE 6. REGRESSION EQUATIONS WHICH INDICATE THE RELATIONSHIP BETWEEN CLOUD HEIGHT AND SOLAR ENERGY FOR THE HOUR ENDING AT NOON, SOLAR TIME, FOR SELECTED PERIODS.

\begin{tabular}{llll}
\hline \multicolumn{1}{c}{ Period } & & Equation & $\begin{array}{c}\text { Correlation } \\
\text { Coefficient }\end{array}$ \\
\hline January & $11-20$ & $\mathrm{~s}=12.9+.10 \mathrm{~h}$ & $.648^{* *}$ \\
February & $11-20$ & $\mathrm{~s}=16.5+.14 \mathrm{~h}$ & $.488^{* *}$ \\
March & $11-20$ & $\mathrm{~s}=21.6+.17 \mathrm{~h}$ & $.632^{* *}$ \\
April & $11-20$ & $\mathrm{~s}=28.7+.15 \mathrm{~h}$ & $.493^{* *}$ \\
May & $11-20$ & $\mathrm{~s}=48.3+.10 \mathrm{~h}$ & $.432^{* *}$ \\
June & $11-20$ & $\mathrm{~s}=45.2+.12 \mathrm{~h}$ & $.361^{*}$ \\
July & $11-20$ & $\mathrm{~s}=51.2+.02 \mathrm{~h}$ & .053 \\
August & $11-20$ & $\mathrm{~s}=48.9+.04 \mathrm{~h}$ & .219 \\
September & $11-20$ & $\mathrm{~s}=-37.9+.06 \mathrm{~h}$ & .160 \\
October & $11-20$ & $\mathrm{~s}=21.9+.12 \mathrm{~h}$ & $.617^{* *}$ \\
November & $11-20$ & $\mathrm{~s}=17.2+.09 \mathrm{~h}$ & $.621^{* *}$ \\
December & $11-20$ & $\mathrm{~s}=13.7+.10 \mathrm{~h}$ & $.620^{* *}$ \\
\hline
\end{tabular}

*correlation significant at $5 \%$ level.

** correlation significant at $1 \%$ level.

tempts to utilize such estimates may lead to disappointing results. If available, pyrheliometric observations should be used during periods with considerable cloudiness.

\section{Daily Values of Solar Radiation and "Percent of Possible" Sunshine}

Only a few weather observing stations are equipped to measure solar radiation. The nearest stations to Columbia, Mo., which maintain such equipment are located at Dodge City, Kan.; Lincoln, Nebr.; Chicago, Ill.; Lexington, Ky.; Little Rock, Ark.; and Oklahoma City, Okla. It is of considerable interest to be able to estimate the solar energy received at other locations or to extend the record at Columbia by estimating the solar radiation received before the installation of the equipment in 1945.

The duration of sunshine should be related to the amount of energy received from the sun. Sunshine duration data will provide a convenient tool for estimating solar radiation for days and places without observational data. Such analyses have been presented by Hamon, et al. (7), Black, et al. (8) and other investigators.

For many years equipment which records the number of minutes of sunshine per day has been used at Columbia and other Weather Bureau Stations in the U. S. This equipment measures the number of minutes with sunshine. Sunshine duration data normally are reported in terms of "percent of possible sunshine." The "percent of possible sunshine" is the fraction of the maximum possible minutes of sunlight that the sun was not obscured by clouds, fog or smoke.

Regression equations showing the linear relationship between solar radiation and "percent of possible sunshine" were computed for Columbia by the one third of a month periods described earlier. These equations, which were based on the 1945-1956 records, are shown in the Appendix with the correlation coef- 
ficient for each period. All correlation coefficients were highly significant, and indicate that the duration of sunshine explains from 62 to 91 percent of the variation in the daily totals of solar radiation. The best relationships were obtained during winter while the poorest correlations were associated with summer. The portion of the variation in solar radiation not explained by the "percent of possible sunshine" is due to differences in cloud density and thickness.

Representative regression lines were plotted for each season of the year, in Figure 10. Note how the amount of energy received on a completely overcast day increases from winter to summer; the slope of the regression line also increases with the approach of the warm season.

Fig. 10-Seasonal relationship between percent possible sunshine and daily solar radiation at Columbia, Mo.

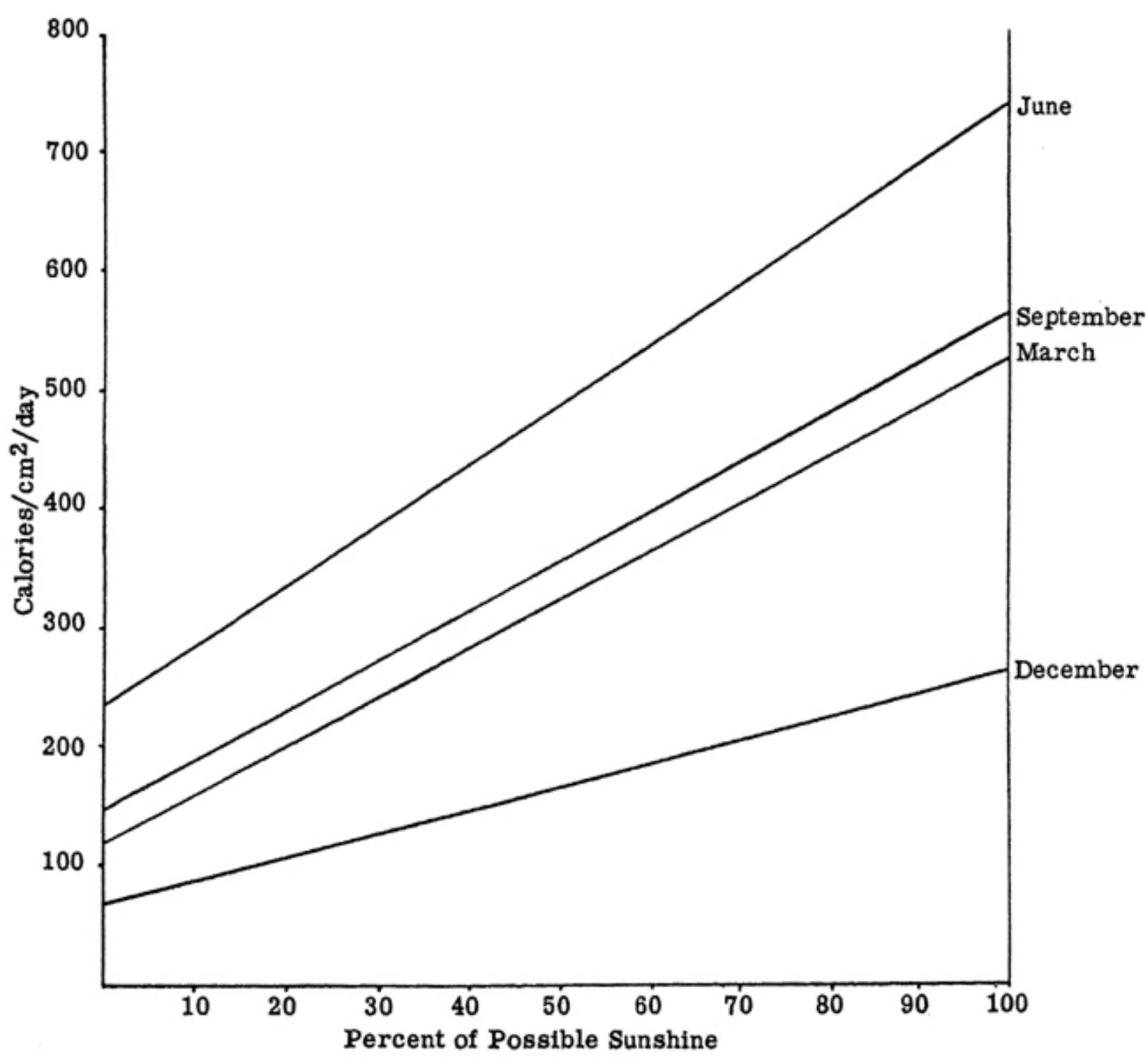


Since these regression analyses were to be used for estimating solar radiation for periods without solar radiation measurements, it was worthwhile to test these relationships with data not employed in the computation of the regression statistics. The regression analyses utilized the data for the period 1945 through 1956, and the records for 1957 were available for testing the accuracy of estimation by the regression analyses.

The mean differences between the estimated and observed radiation and the standard deviation of these differences are shown for each season of 1957 in Table 7.

TABLE 7. COLUMBIA, MISSOURI

\begin{tabular}{lcc}
\hline Season & $\begin{array}{c}\text { Mean difference } \\
\text { Observed-computed }\end{array}$ & $\begin{array}{c}\text { Standard } \\
\text { Deviation }\end{array}$ \\
\hline Winter & +1.3 & 36.6 \\
Spring & -4.3 & 58.6 \\
Summer & -12.0 & 60.2 \\
Fall & 2.9 & 40.8 \\
\hline
\end{tabular}

The average differences between the observed and the computed solar radiation are not great. Even in summer with an average difference of -12 calories per day, this difference is only 2 to 2.5 percent of the 500 to 600 calories of energy received on an average summer day. The magnitude of the standard deviations of Table 7, which are of the same order as the standard errors of estimate obtained in the regression analyses, indicate that caution should be exercised in applying the equations to daily estimates of solar radiation. In summer one would expect. 68 percent of the daily differences between the observed and the computed values to fall between -72 and +48 calories/ $\mathrm{cm}^{2} /$ day. This difference of 120 calories is equivalent to the energy required to evaporate about 0.08 of inch of water, and it is sufficient to increase the temperature of soil covered with grass about $1^{\circ} \mathrm{F}$ at the 3 -inch depth. Computed values may approximate the average of the daily intensity of solar energy, but the computed values for individual days may be in error. When measurements of solar radiation to a high precision are required, pyrhelometric observations which directly measure the amount of energy should be employed.

\section{COMPARATIVE ESTIMATES OF SOLAR RADIATION FOR OTHER GEOGRAPHIC LOCATIONS}

If the earth had no atmosphere, the amount of solar energy reaching any point on earth surface, according to the Humphrey (9), would be a function of the cosine of the zenith angle of the sun (see Figure 11), the solar constant and of the distance from the sun to the earth. For any day the solar constant and the 
Fig. 11-Schematic diagram showing zenith and declination angles for a point on the earth.

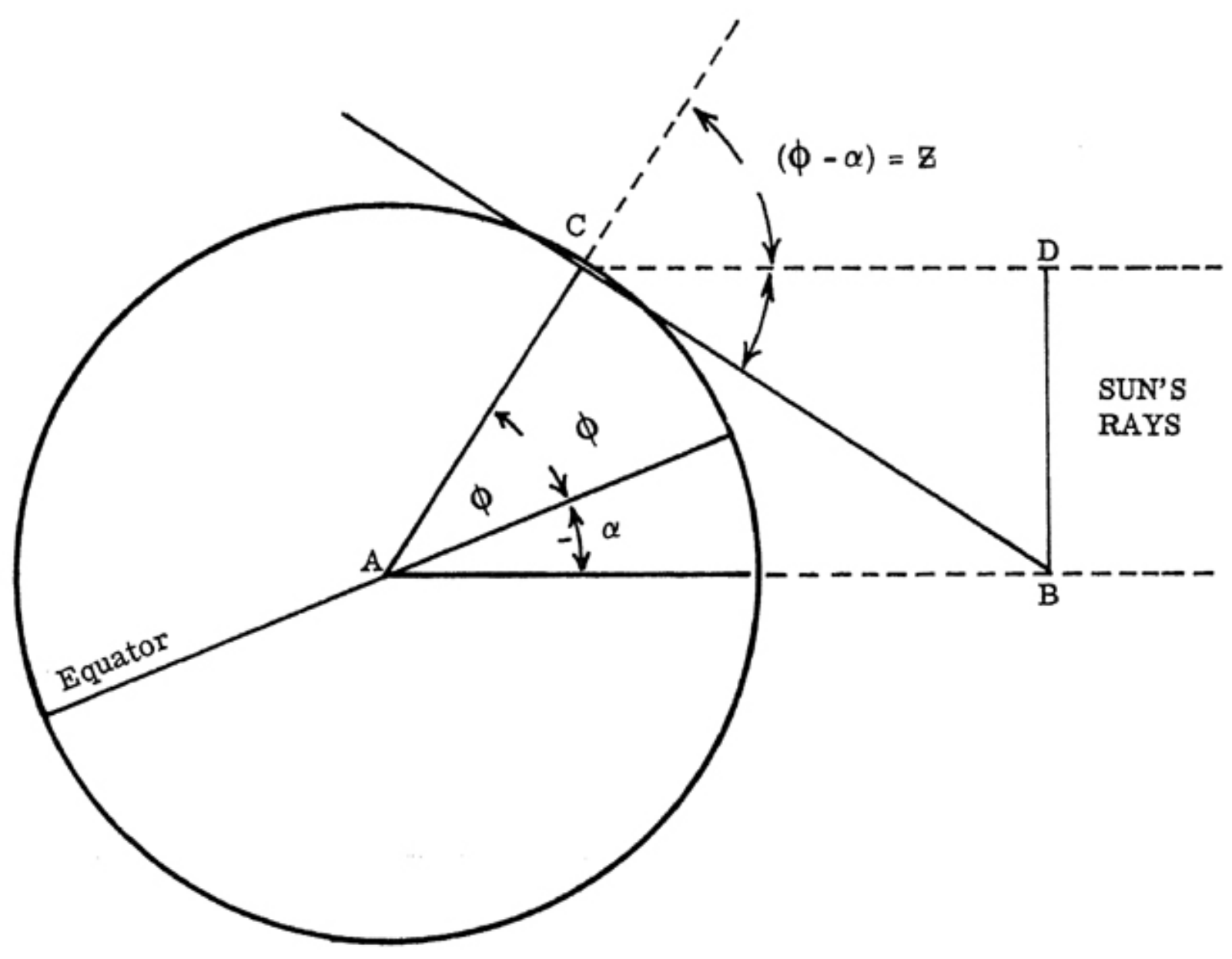

distance of the earth from the sun will be essentially the same at all locations in Missouri. The ratio of solar radiation at two locations in the state is a function of the ratio of the cosines of their respective zenith angles. $\dagger$

Figure 11 gives the definition of the angles employed in this derivation. For any date and point on the earth's surface the value of $\mathrm{Z}$, which is the zenith

†This cosine relationship is theoretically true for apparent noon. A more exact expression for the entire day would include the hour angle, which is the angle described by the sun as it travels from the position at sunrise to its position at apparent noon. If $\mathrm{H}$ is the hour angle, $\operatorname{Cos} \mathrm{H}=-\tan \varphi \tan \alpha$. The exact expression for the ratio of the total of daily radiation at two locations is defined by the ratio of the following quantity for each location.

$\mathrm{H} \sin \varphi \sin \alpha+\sin \mathrm{H} \cos \varphi \cos \alpha$

Where $\mathrm{H}$ is the hour angle, $\varphi$ the latitude and $\alpha$ the declination angle. Since the discrepancy between this exact ratio and the ratio of the cosines of the zenith angles is never greater than 2 percent for Missouri locations the latter expression was used for these comparisons. 
Fig. 12-A comparison of the daily averages of computed solar energy at three locations in Missouri based on long-time averages of percent of possible sunshine.

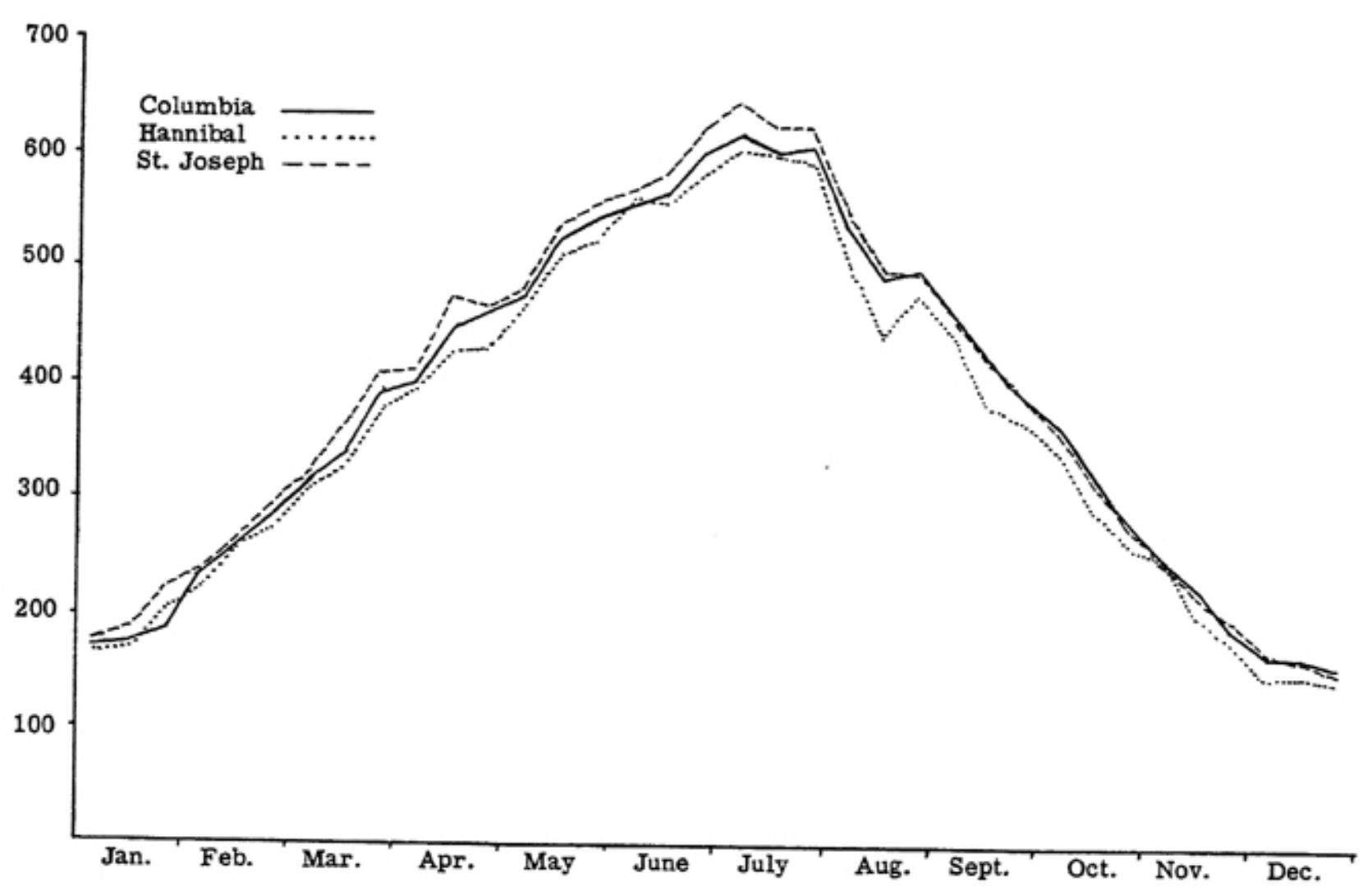

angle, can be determined by subtracting, algebraically, the declination angle of the sun from the latitude of the point. The values of the declination angles for each location and date may be found in tables prepared by Smithsonian Institute (10).

\section{Let}

$Z_{c}$ be the zenith angle for Columbia at a given time and date.

$Z_{x}$ be the zenith angle for another location at the same time and date.

$R_{c}$ and $R_{x}$ be the expected solar radiation at Columbia and at position $x$, respectively for a given "percent of possible sunshine".

Then it follows that:

$$
\frac{R_{x}}{R_{c}}=\frac{\operatorname{Cos} Z_{x}}{\operatorname{Cos} Z_{c}}
$$

and

$$
R_{x}=\frac{\left(\operatorname{Cos} Z_{x}\right)}{\left(\operatorname{Cos} Z_{c}\right)}(R c) \text {. }
$$

The value of $R_{c}$ is computed from the regression equations relating solar energy to "percent of possible sunshine." The sunshine records for point X must be used in obtaining $R_{c}$. The ratio of $\operatorname{Cos} Z_{x}$ and $\operatorname{Cos} Z_{c}$ will adjust $R_{c}$ for the dif- 
Fig. 13-A comparison of the daily averages of computed solar energy at three locations in Missouri based on long-time averages of percent of possible sunshine.

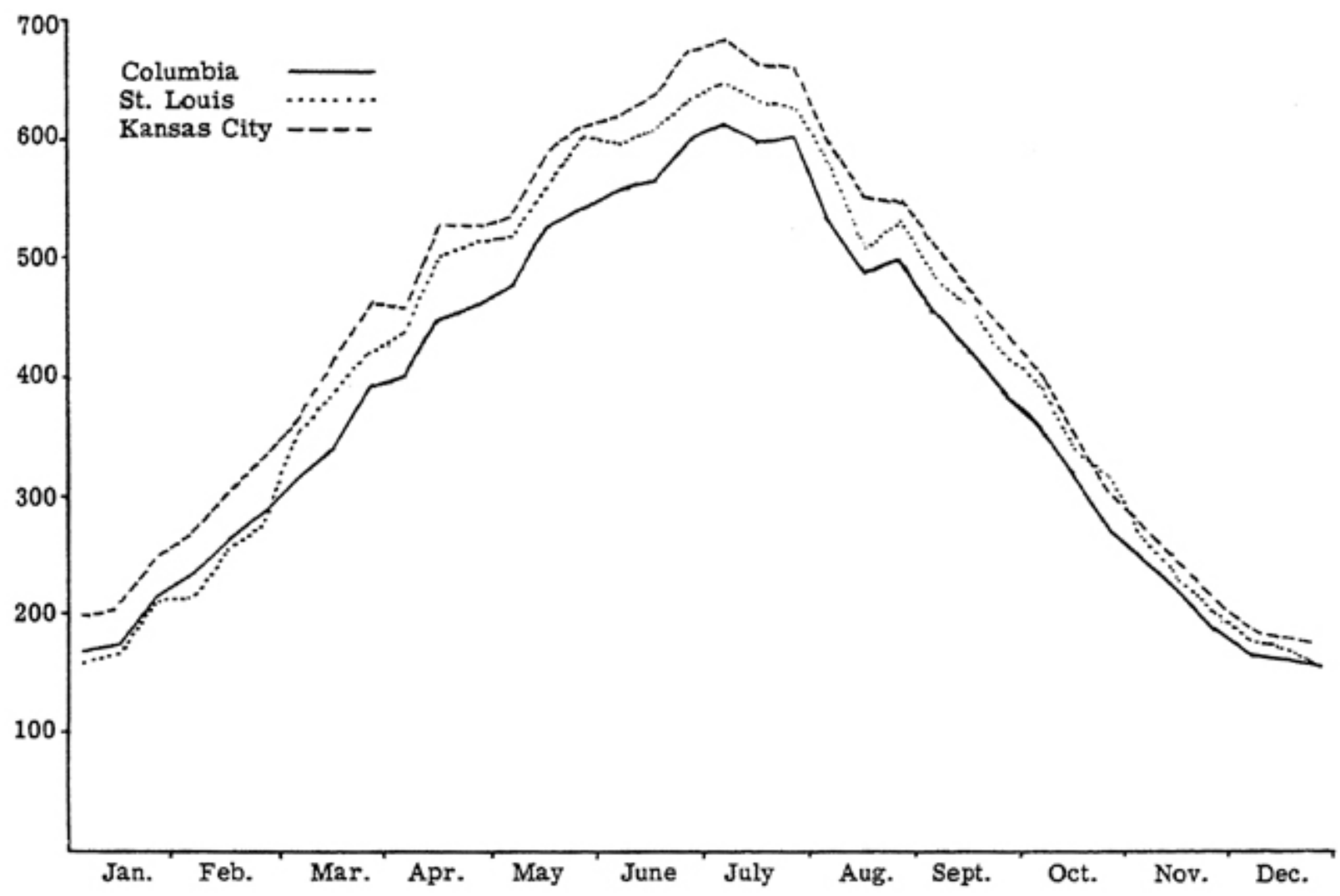

ference in latitude between Columbia and Point X.

The average daily radiation for other locations in Missouri have been computed by use of equation (1). Results of these computations are in Figures 12, 13, and 14. As expected, the southern portion of the state was estimated to receive more radiation than Columbia. Northwestern Missouri, with less cloudiness than Columbia, received greater amounts of energy.

These estimates of the average solar energy are only approximations of what might be experienced at different locations in the state. When accurate data concerning solar radiation are needed, proper and carefully exposed instruments for measuring solar energy must be employed. 
Fig. 14-A comparison of the daily averages of computed solar energy at three locations in Missouri based on long-time averages of percent of possible sunshine.

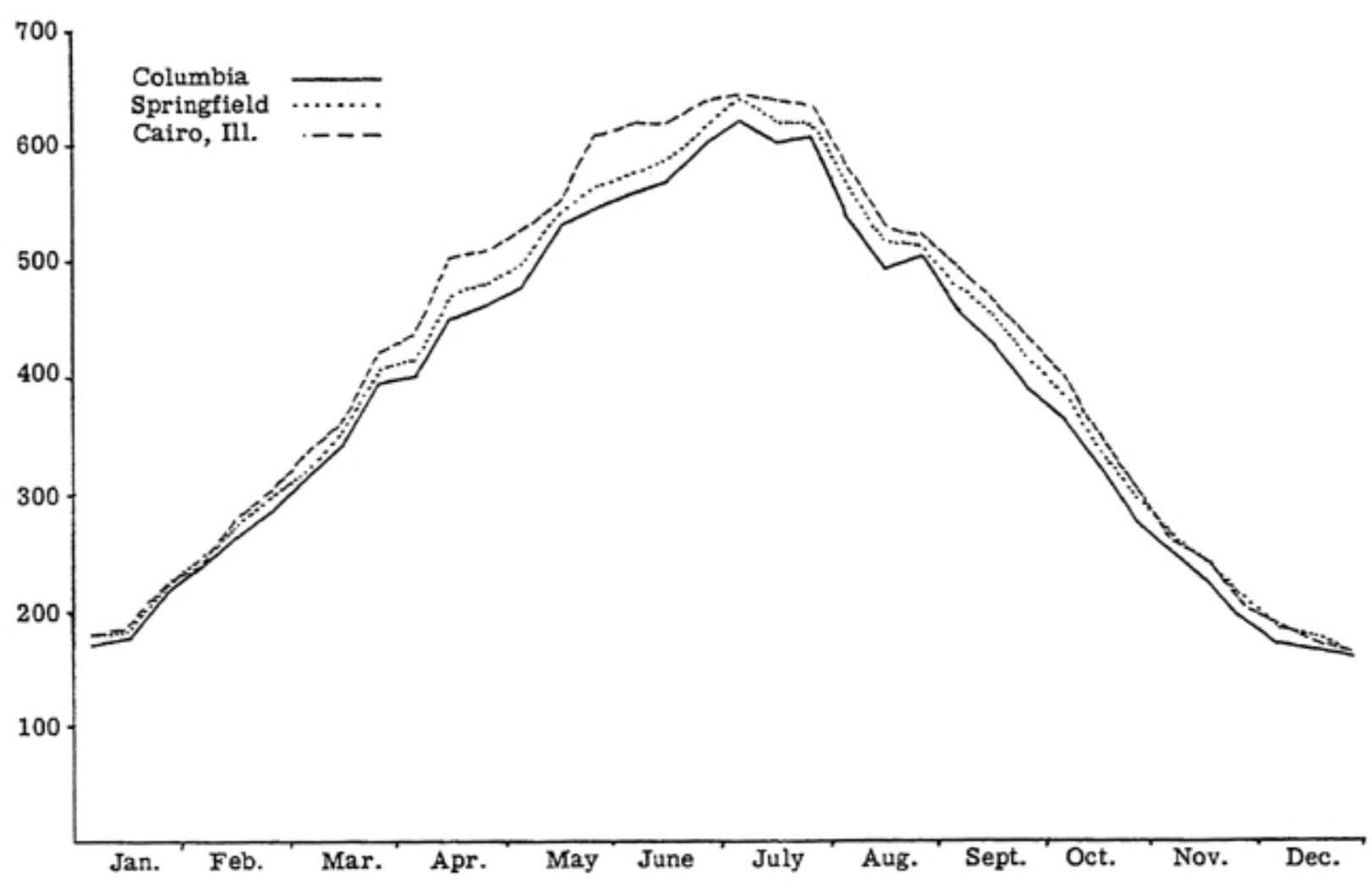

\section{REFERENCES}

1. Fritz, Segmund, Solar Radiant Energy and Its Modification by the Earth and Its Atmosphere: Compendium of Meteorology, 13-33, American Meteor. Soc., Boston, 1951.

2. Buelow, F. H., Grain Drying with Solar Heat, Progress Report: Unpublished Note, Michigan State University, December, 1957.

3. Penman, H. L., Natural Evaporation from Open Water, Bare Soil and Grass: Proc. Roy. Soc. A, 193:120-146, 1948.

4. Gardner, V. R., Merrill, T. A., and Toenjes, W., Fruit Setting in the Delicious Apple: Michigan Agr. Expt. Stat., Special Bulletin, 358, June, 1949.

5. The Epply Pyrheliometer Manual, Bulletin 2, Epply Laboratory, Inc., Newport, R. I.

6. University of Missouri Seventh Annual Progress Report, Missouri Climatological Research Project: Mimeographed Notes, Columbia, Missouri, July, 1955.

7. Hamon, R. W., Weiss, L. L., and Wilson, W. T., Insolation as an Empirical Function of Daily Sunshine Duration, Mon. Wea. Rev. 82, 141-116, 1954.

8. Black, J. N., Boynthow, C. W., and Prescott, J. A., Solar Radiation and the Duration of Sunshine, Quart. Jour. Roy. Meteor. Soc. 80, 231-235, 1954.

9. Humphreys, W. J., Physics of the Air, 3rd Edition, McGraw-Hill, Pp. 88, New York, 1940.

10. Smithsonian Institute, Smithsonian Meteorological Tables, Gth Rev. Edition, Washington, D. C., 1951. 
APPENDIX

REGRESSION EQUATIONS AND CORRELATION COEFFICIENTS WHICH RELATE THE PERCENT OF POSSIBLE SUNSHINE WITH SOLAR RADIATION AT COLUMBLA, MO.; DATA BASED ON 1945-1956 RECORDS.

\begin{tabular}{|c|c|c|c|}
\hline Period & $\begin{array}{c}\text { Regression } \\
\text { Equation } 1\end{array}$ & $\begin{array}{r}\text { Correlation }{ }^{2} \\
\text { Coefficient }\end{array}$ & $\begin{array}{l}\text { Number } \\
\text { of Days }\end{array}$ \\
\hline January $1-10$ & $\mathrm{R}=58.9+223.1 \mathrm{~S}$ & .945 & 97 \\
\hline January $11-20$ & $\mathrm{R}=70.3+222.7 \mathrm{~S}$ & .952 & 99 \\
\hline January 21-31 & $\mathrm{R}=76.2+262.6 \mathrm{~S}$ & .954 & 109 \\
\hline February $1-10$ & $R=81.7+284.9 S$ & .938 & 110 \\
\hline February 11-20 & $\mathrm{R}=82.1+327.9 \mathrm{~S}$ & .948 & 109 \\
\hline $\begin{array}{c}\text { February 21-28 } \\
\text { (29) }\end{array}$ & $\mathrm{R}=100.9+351.9 \mathrm{~S}$ & .944 & 89 \\
\hline March 1-10 & $R=100.3+384.2 S$ & .916 & 109 \\
\hline March 11-20 & $\mathrm{R}=120.4+409.1 \mathrm{~S}$ & -904 & 110 \\
\hline March 21-31 & $R=122.3+468.2 S$ & .930 & 121 \\
\hline April $1-10$ & $\mathrm{R}=133.6+485.3 \mathrm{~S}$ & .913 & 109 \\
\hline April 11-20 & $\mathrm{R}=141.4+539.6 \mathrm{~S}$ & .937 & 101 \\
\hline April 21-30 & $\mathrm{R}=124.0+568.0 \mathrm{~S}$ & .943 & 99 \\
\hline May $1-10$ & $\mathrm{R}=163.8+522.5 \mathrm{~S}$ & .908 & 100 \\
\hline May $11-20$ & $\mathrm{R}=192.6+528.3 \mathrm{~S}$ & .899 & 105 \\
\hline May 21-31 & $R=204.9+531.2 S$ & .887 & 121 \\
\hline June $1-10$ & $\mathrm{R}=243.8+491.6 \mathrm{~S}$ & .885 & 110 \\
\hline June 11-20 & $\mathrm{R}=236.7+502.7 \mathrm{~S}$ & .907 & 109 \\
\hline June 21-30 & $\mathrm{R}=206.2+548.8 \mathrm{~S}$ & .903 & 99 \\
\hline July $1-10$ & $\mathrm{R}=253.2+488.3 \mathrm{~S}$ & .896 & 119 \\
\hline July $11-20$ & $R=283.6+436.5 S$ & .845 & 116 \\
\hline July 21-31 & $\mathrm{R}=313.0+394.1 \mathrm{~S}$ & .794 & 124 \\
\hline August $1-10$ & $\mathrm{R}=222.6+458.4 \mathrm{~S}$ & .874 & 110 \\
\hline August 11-20 & $\mathrm{R}=195.2+444.4 \mathrm{~S}$ & 880 & 117 \\
\hline August 21-31 & $R=174.5+456.0 S$ & .927 & 130 \\
\hline September $1-10$ & $R=155.7+448.9 \mathrm{~S}$ & .943 & 119 \\
\hline September 11-20 & $R=146.0+417.0 \mathrm{~S}$ & .920 & 119 \\
\hline September 21-30 & $R=140.7+394.8 S$ & .938 & 120 \\
\hline October $1-10$ & $\mathrm{R}=145.2+333.5 \mathrm{~S}$ & .920 & 120 \\
\hline October $11-20$ & $\mathrm{R}=113.4+322.4 \mathrm{~S}$ & 918 & 120 \\
\hline October 21-31 & $\mathrm{R}=110.4+281.7 \mathrm{~S}$ & .935 & 121 \\
\hline November $1-10$ & $\mathrm{R}=89.2+276.2 \mathrm{~S}$ & .958 & 99 \\
\hline November $11-20$ & $R=101.0+217.2 S$ & .926 & 91 \\
\hline November $21-30$ & $\mathrm{R}=87.4+207.2 \mathrm{~S}$ & .905 & 100 \\
\hline December $1-10$ & $\mathrm{R}=71.0+206.5 \mathrm{~S}$ & .923 & 100 \\
\hline December $11-20$ & $\mathrm{R}=67.0+197.0 \mathrm{~S}$ & .940 & 107 \\
\hline December 21-31 & $\mathrm{R}=66.6+196.1 \mathrm{~S}$ & .924 & 120 \\
\hline
\end{tabular}

IR is the daily radiation in calories/ $\mathrm{cm}^{2} /$ day; $\mathrm{S}$ is the ratio of total minutes of sunshine to the total possible minutes of sunshine.

2 All correlation coefficients are significant at the 99 percent level. 